\title{
THE ROLE OF CULTURE WITH FESTIVAL ENTREPRENEURS
}

\author{
Martinette Kruger: Institute for Tourism and Leisure Studies, Potchefstroom \\ Lara Engelbrecht: Institute for Tourism and Leisure Studies, Potchefstroom \\ Melville Saayman: Institute for Tourism and Leisure Studies, Potchefstroom
}

\begin{abstract}
Purpose: The goal of the study was to determine the influence of cultural differences on entrepreneurship at the Grahamstown National Arts Festival.

Problem investigated: The Grahamstown National Arts Festival is one of the most important arts festivals on the South African cultural calendar. Diverse entrepreneurs make use of the opportunities created by the festival. However, these entrepreneurs are heavily influenced by their cultural traits. This is because culture has an effect on the general decision making, standards, the behavioural patterns and ways of behaviour in SMMEs (small, medium and micro-enterprises). With the festival's significant annual growth and its economic value in mind, determining the role that culture plays on the individuals' motivation to embark on an entrepreneurial career is essential. How this influences the way they perceive their role at the festival is of vital importance to the festival marketers, organisers and even the South African Government (since it is largely responsible for creating a favourable entrepreneurial climate in the country).
\end{abstract}

Design and methodology: Within the study, a distinction was made between different cultural groups at the Grahamstown National Arts Festival: White entrepreneurs, Black entrepreneurs, Indian entrepreneurs and Coloured entrepreneurs. ANOVAs were used to determine whether there were differences between these cultures.

Findings and/or implications: The results of the study showed statistically significant cultural differences between these groups based on their socio-demographic characteristics, entrepreneurial attributes, motivation to attend as well as their perceived role at the festival.

Originality and/or value of the research: This was the first time that research of this kind was conducted at a national arts festival in South Africa. The research has shown that by acknowledging and managing entrepreneurs' unique characteristics and traits represented by different cultural subgroups at the festival, a thriving entrepreneurial environment can be ensured.

Conclusion: With the aim of achieving a successful entrepreneurial environment, factors that promote cross cultural entrepreneurship need to be an integral facet of entrepreneur-directed education, training and management as this will develop a positive orientation to entrepreneurship.

Key words: Culture, attributes, Grahamstown, entrepreneur, festival, tourism

\section{INTRODUCTION}

Festivals are growing at a significant rate in South Africa with attendees being able to choose between an average of four festivals per month (Van Zyl \& Strydom, 2007:121-122). Apart from extending the tourist season and generating revenue for governments, hosting festivals has positive economic impacts on the local economy by generating income, supporting existing businesses and encouraging new businesses (Snowball, 2004:1081; Fredline, Jago \& Deery, 2003:23; Gursoy, Kim \& Uysal, 2004:171; Jackson \& O'Sullivan, 2002:328; Dwyer, Forsyth \& Spurr, 2005:351). Festivals and events are therefore a perfect setting for encouraging entrepreneurial ventures within the tourism industry. Saayman, Douglas and De Klerk (2008:13) proved that national arts festivals in the country attract entrepreneurs from small businesses across South Africa to promote their businesses and stimulate entrepreneurial opportunities in areas such as accommodation, attractions, crafts and foods (Tyson, Hayle, Truly, Jordan \& Thame, 2005:327). 
The Grahamstown National Arts Festival (GNAF) is one such South African national arts festival that creates a platform for new ideas, not just within the arts but from an entrepreneurial point of view. It creates a chance for small business owners to enter the market. Being the oldest national arts festival in the country, the festival has, for the past 35 years, been one of the most important arts festivals/events on the South African cultural calendar. Starting at the end of June/beginning of July, it runs for between 8 and 10 days and is held in the small university city of Grahamstown located in the Eastern Cape Province (see Map 1) (Anon, 2008).

\section{Map 1: Location of Grahamstown, host city of the Grahamstown National Arts Festival}

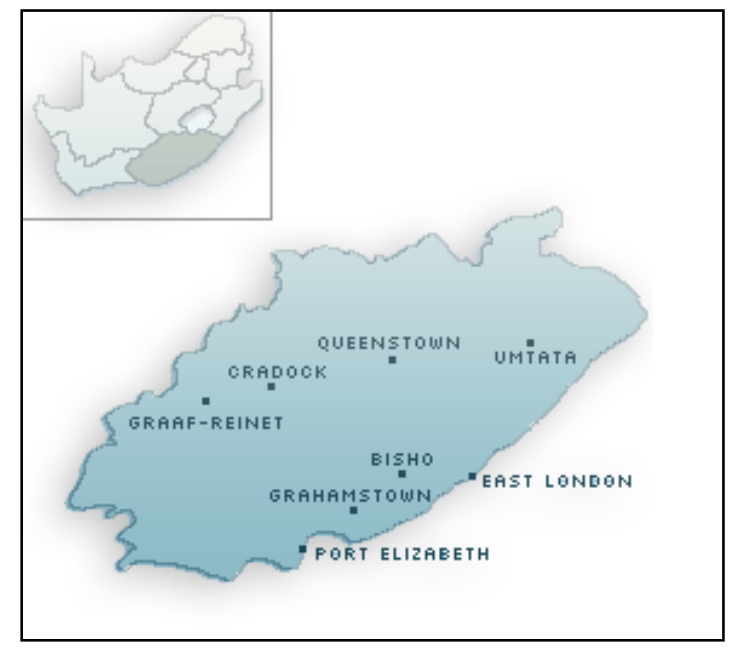

In contradiction to most other national arts festivals held in the country that focus on the Afrikaansspeaking market, this festival targets the English-speaking market. This is not only reflected in the festinos attending the festival, but also the entrepreneurs from different cultural backgrounds. A festival entrepreneur is defined by Jonker, Saayman and De Klerk (2009:383) as someone who started and manages his/her own business, who travels from festival to festival in order to promote, offer or sell his/her product or services as well as creating or adding new ones. Based on this, Urban (2006:172) points out that how successfully these diverse entrepreneurs make use of the opportunities created by the festival is heavily influenced by their cultural traits. This is because culture has an affect on the general decision making, standards, the behavioural patterns and ways of behaviour in SMMEs (small, medium and micro-enterprises) (Visagie, 1999:148-162). There is, therefore, a significant connection between entrepreneurship and cultural specificity (Morrison, 2000:59).

With this in mind, the objective of this article is to determine the influence of cultural differences on entrepreneurship at the GNAF. The focus is on discovering the role that culture plays on the individuals' motivation to embark on an entrepreneurial career and how this influences the way they perceive their role at the festival. To achieve this, the article is structured in the following manner: a literature review is followed by a description of the survey and a discussion of the results and, finally, the implications and conclusions are presented.

\section{LITRATURE REVIEW}

According to Urban (2006:172), South Africa is a culturally heterogeneous society and is referred to as the 'Rainbow Nation' - mostly due to its diversity in people, cultures, languages and religions (Nieman, 2001:445). There are more than 12 different cultural groups in South Africa (Botha, 2006:28) and, with the country's diversity and multiculturalism in mind (Human, 1993:46), a great deal of attention is being placed on stimulating SMME development in South Africa by providing financial incentives, creating infrastructure and deregulating restrictive legislation (Mitchell, 2003:724). However, the 2008 Global 
Entrepreneurship Monitor (GEM) report shows that South Africa has the lowest total entrepreneurship activity (TEA) rate of any developing country measured. This means that entrepreneurial activity on a range of measures is extremely low (Herrington, Kew \& Kew, 2008:4). This leads to serious concerns about the South African SMME sector's potential to contribute meaningfully to job creation, economic growth and more equal income distribution. The report furthermore emphasises that culture, and, especially racial ethnicity, still have a strong influence on entrepreneurial activity in the country with Whites and Indians being more likely to start a business compared to Coloureds or Blacks (Herrington et al., 2008:4). Unfortunately, the results of the GEM report also support the notion by Davies (2001:32) that the existing entrepreneurial base in South Africa is neither wide nor solid.

However, as Orford, Wood, Fischer, Herrington and Segal (2003) point out, many individuals have the desire to pursue entrepreneurial ventures but are not engaging, not because they do not have the knowledge and skills, but because they are lacking in self-belief. Both Weber (1958) and Schumpeter (1934) argued that the source of entrepreneurial behaviour is laid in the social structure of societies and the value structures they produce. Morrison (2000:59) agrees, and stresses that the key to initiating the process of entrepreneurship lies within the individual members of society, and the degree to which a spirit of enterprise exists, or can be initiated. Minniti and Bygrave (2003) add that cultural and social norms are the major strength of entrepreneurship orientation and seem to be the differentiating factor for higher levels of entrepreneurial activities. Cultural values indicate the degree to which a society considers entrepreneurial behaviours, such as risk taking and independent thinking, as desirable (Hayton, George \& Zahra, 2002:33). This is because culture affects attitude including attitude towards new venture creation and development as well as associated entrepreneurial behaviour (Lindsay, 2005:3).

Although Hofstede (1991) does not specify the relationship between entrepreneurship and culture, his dimensions are well documented and nonetheless useful in identifying the criteria of culture related to entrepreneurship (Urban, 2006:173). His framework contains five dimensions that he believes can be used to differentiate between cultures (also referred to in Morrison, 2000:60; Lee \& Peterson, 2000:404; Saffu, 2003):

1. Power distance: the degree of inequality among people that the population of a country consider normal.

2. Individualism: the degree to which people in a country prefer to act as individuals rather than members of groups.

3. Masculinity: the degree to which such 'masculine' values, such as assertiveness, competitiveness, and success are emphasised, as opposed to 'feminine' values such as quality of life, warm personal relationships, service, etc.

4. Uncertainty avoidance: the degree to which people in a country prefer structured over unstructured situations.

5. Long-term orientation: long-term orientation implies a stress on virtuous living in this world, with thrift and persistence as key virtues.

Based on Hofstede's (1991) framework, researchers have, in general, hypothesised that entrepreneurship is facilitated by cultures that are high in individualism, low in uncertainty avoidance, low in power distance, and high in masculinity (Hayton et al., 2002:34; Lee \& Peterson, 2000:405). Thus it can be assumed that the greater the distance from this ideal type, the lower the average individual and aggregate levels of entrepreneurship and that some cultures or social groups are therefore more in favour of entrepreneurial behaviour than others (Lee \& Peterson, 2000:404; Minniti \& Bygrave, 2003; Mueller \& Thomas, 2000:52). This also seems to be the case in South Africa, since the majority of South Africans have grown up with little home experience of business innovation or entrepreneurship and hence do not view themselves as having this potental (Co \& Mitchell, 2006:349). Co (2003:40) also points out that most black South Africans prefer the security of a full time job rather than the uncertainty of generating income from running one's own business. 


\section{Engelbrecht \\ M. Kruger \\ M. Saayman}

Taking advantage and adapting to the country's cultural diversity is therefore a key aspect when creating entrepreneurial opportunities, providing the necessary support and looking at the South African entrepreneur (Visser, de Coning \& Smit, 2005:51). This is an important consideration, since the small business sector in South Africa has the potential not only to contribute to job creation and economic growth but, at the same time, redress historical imbalances and increase Black Economic Empowerment (Luiz, 2000:5). Creating an entrepreneurial culture where entrepreneurship is encouraged in the country is therefore dependent on a wide array of environmental or societal constructs which include economic, political/legal and social forces (Lee \& Peterson, 2000:407). However, as mentioned earlier, the society's diversity in culture (historical experiences, beliefs, attitudes and values) also significantly contribute to the growth or reduction of an entrepreneurial culture (Gordon, 1996). According to Minniti and Bygrave (2003:20), the core of entrepreneurial orientation lies within a country's culture and social norms. Culture therefore needs to be taken into consideration when fostering and managing an entrepreneurial culture with the help of national arts festivals in South Africa, such as the GNAF. Based on this, the relationship between culture and entrepreneurship is illustrated in the model (Figure 1) below.

Figure 1: Model of the relationship between culture and entrepreneurship

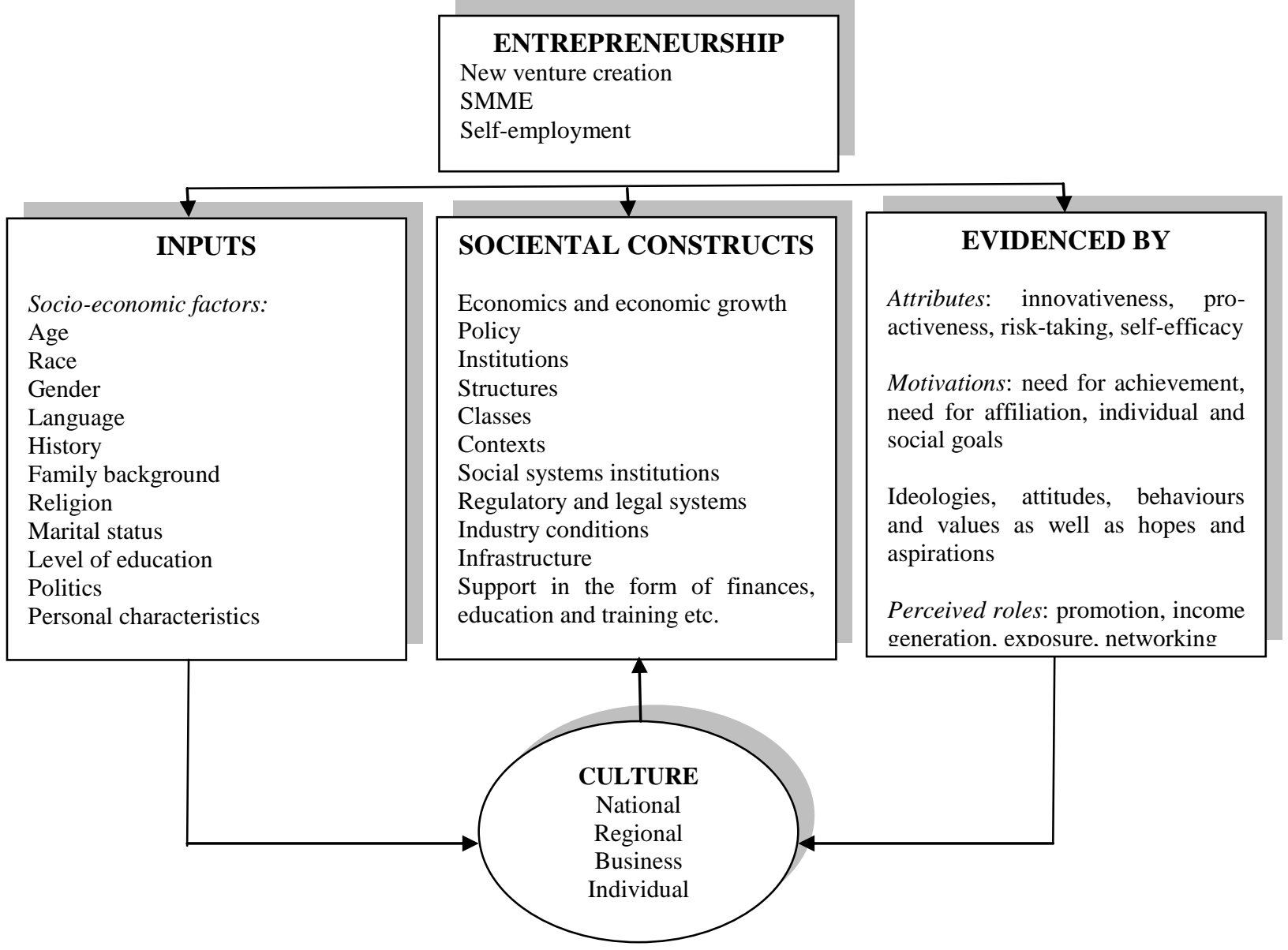

Source: Adapted from Hayton et al. (2002:46), Morrison (2000:69), Lindsay (2005:2), Lee and Peterson (2000:410)and Maasdorp and Van Vuuren (1998:727)

As shown in the model (Figure 1), a certain range of Inputs, Societal constructs and Evidence is significant to the initiation of entrepreneurship within different cultures. Concerning Inputs, research reveals that that there is a range of socio-economic factors that can either stimulate and encourage or 

L. Engelbrecht
M. Kruger
M. Saayman

constrain individuals from different cultures to launch entrepreneurial ventures and continue as entrepreneurs (Co, 2003:35; Mitchell, 2003:726). The socio-economic factors that seem to have the most significant influence on entrepreneurship are outlined in Table 1 below.

Table 1: Main findings concerning socio-economic factors influencing

\begin{tabular}{|c|c|}
\hline $\begin{array}{l}\text { Socio-economic } \\
\text { factor }\end{array}$ & Main findings \\
\hline Family background & $\begin{array}{l}\text { Entrepreneurs tend to have self-employed fathers (Hisrich \& Peters, } \\
\text { 1998; Lordkipanidze, Brezet \& Backman, 2005:789). } \\
\text { Children growing up with the background of a family business and who } \\
\text { are thus exposed to mentorship on a daily basis are more inclined to be } \\
\text { entrepreneurs (Co, 2003:39). } \\
\text { Business acumen does not necessarily run in families (Nair \& Panday, } \\
\text { 2006:60). }\end{array}$ \\
\hline Financial status & $\begin{array}{l}\text { The more economically better-off a family, the greater the chances of } \\
\text { embarking on entrepreneurial ventures and succeeding in them (Nair \& } \\
\text { Panday, 2006:60; Brislin, 2000:119; Mitchell, 2003:728). }\end{array}$ \\
\hline Family support & $\begin{array}{l}\text { - Family support, especially the role of the family in enabling access to } \\
\text { funds and markets, contributes to the creation and development of } \\
\text { entrepreneurial ventures (Morrison, 2000:69). } \\
\text { - The manner in which the young are conditioned from an early age } \\
\text { through the formal education system and family life also plays a } \\
\text { significant role in the initiation of characteristics generally associated with } \\
\text { entrepreneurial behaviour (Schindehutte, Morris \& Brennan, 2003:94). } \\
\text { - It is not only the values taught by elders that play a role, but also } \\
\text { experiences during childhood within the community (Breslin, 2000:9). }\end{array}$ \\
\hline Level of education & $\begin{array}{l}\text { - Successful entrepreneurs have a higher level of education and seem to } \\
\text { use opportunities more (Co \& Mitchell, 2006:349-350; Bogan \& Darity Jr., } \\
\text { 2008:2000; Brink, Cant \& Ligthelm, 2003:19). }\end{array}$ \\
\hline Acquired skills & $\begin{array}{l}\text { Both technical education/training and work experience in a similar or } \\
\text { related field furthermore positively affect entrepreneurship (Nair \& } \\
\text { Panday, 2006:60; Hisrich \& Peters, 1995). }\end{array}$ \\
\hline Age & $\begin{array}{l}\text { - Maturity in age favours success in entrepreneurial ventures (Nair \& } \\
\text { Panday, 2006:60). } \\
\text { Individuals between the age of } 25 \text { and } 44 \text { are most likely to be involved in } \\
\text { entrepreneurial activity (Jonker et al., 2009; Reynolds, Bygrave, Autio, } \\
\text { Cox \& Hay, 2002). }\end{array}$ \\
\hline Gender & $\begin{array}{l}\text { Entrepreneurship is largely seen as being dominated by males (Human, } \\
\text { 1993:50; Brislin, 2000:323; Saffu, 2003:70; Botha, 2006:28; Chitsike, } \\
\text { 2000:72-73). } \\
\text { - However, more female entrepreneurs are seeking independence, } \\
\text { opportunities and accepting challenges (Brislin, 2000:129). }\end{array}$ \\
\hline Religion & $\begin{array}{l}\text { - The religious community to which one belongs dos not impact individuals' } \\
\text { venturing into entrepreneurial pursuits or succeeding in them (Nair \& } \\
\text { Panday, 2006:60). }\end{array}$ \\
\hline $\begin{array}{l}\text { Race and business } \\
\text { ventures }\end{array}$ & $\begin{array}{l}\text { - Whites and Indians are more likely to start a business than Coloureds or } \\
\text { Blacks (Herrington et al., 2008:23). } \\
\text { - Whites are also more prone to start a business earlier (at a younger age) } \\
\text { compared to Blacks (Herrington et al., 2008:23). }\end{array}$ \\
\hline
\end{tabular}



L. Engelbrecht
M. Kruger
M. Saayman

THE ROLE OF CULTURE WITH FESTIVAL ENTREPRENEURS

Based on the information reflected in the table above, each entrepreneur has their own unique set of personal characteristics (Inputs) which are then translated into entrepreneurial activities and behaviour (Morrison, 2000:68). Given the prominent role of the government in initiating and supporting entrepreneurial opportunities, certain Societal constructs (Figure 1) influence the establishment of an entrepreneurial culture in a country. Both Inputs and Societal constructs have an effect on the different levels of culture (national, regional, business and individual) that can be Evidenced relative to entrepreneurial attributes, motivations, perceived role, ideological practices, and cultural attitudes, values and beliefs (Morrison, 2000:68; Morris, Davis \& Allen, 1994:70). The influence of culture on the latter is summarised in Table 2. 
M. Saayman

\section{Table 2: The influence of culture on entrepreneurial evidence}

\begin{tabular}{|c|c|c|}
\hline Evidence & Findings & Author(s) \\
\hline $\begin{array}{l}\text { Entrepreneurial attributes among different } \\
\text { cultures }\end{array}$ & $\begin{array}{l}\text { Five salient attributes of successful entrepreneurship which can also apply to different } \\
\text { cultural groups: } \\
\text { - Autonomy (act independently, maintain personal control and to seek opportunities } \\
\text { in the absence of societal constraints). } \\
\text { - Innovation (the development of novel or unique products, services and } \\
\text { processes). } \\
\text { - Risk taking (a willingness to pursue opportunities having a reasonable chance of } \\
\text { costly failure). } \\
\text { - Pro-activeness (an emphasis on persistence and creativity in overcoming } \\
\text { obstacles until the innovative concept is fully implemented). } \\
\text { - Competitive aggression (achievement orientated to improve their position relative } \\
\text { to competition). }\end{array}$ & $\begin{array}{l}\text { Lee and Peterson (2000:405- } \\
407) ; \\
\text { Morris, Davis and Allen } \\
(1994: 69)\end{array}$ \\
\hline \multirow[t]{5}{*}{$\begin{array}{l}\text { Entrepreneurial motives between different } \\
\text { cultures }\end{array}$} & $\begin{array}{l}\text { Family circumstances, economic pressure, the urge for economic independence, } \\
\text { life-path changes and the urge to improve economic status were the major } \\
\text { motivating factors for African women to become entrepreneurs. }\end{array}$ & Kuiper (1993) \\
\hline & $\begin{array}{l}\text { - External approval, personal development, recognition, need for independence and } \\
\text { influence in the community, benefits and security were the common motivating } \\
\text { factors among entrepreneurs in rural South Africa. }\end{array}$ & Mitchell (2004:167) \\
\hline & $\begin{array}{l}\text { - Innovation, independence, outstanding performance, need for achievement and } \\
\text { respect for work are the most common motivational characteristics recognised in } \\
\text { entrepreneurs. }\end{array}$ & $\begin{array}{l}\text { Vijaya and Kamalanabhan } \\
\text { (1998) }\end{array}$ \\
\hline & $\begin{array}{l}\text { Desire for independence, greater control over their lives, improvement of their } \\
\text { social status in the eyes of their own community and making the best use of their } \\
\text { expertise. }\end{array}$ & Basu and Altinay (2000) \\
\hline & $\begin{array}{l}\text { - Cultural values do not seem to have a strong and clear relationship with } \\
\text { entrepreneurial intentions (motivations) in South Africa. }\end{array}$ & Urban (2006:182) \\
\hline
\end{tabular}


L. Engelbrecht

M. Kruger

THE ROLE OF CULTURE WITH FESTIVAL ENTREPRENEURS

M. Saayman

Perceived role of entrepreneurs at festivals and events
- Initial exposure, credibility, promotion, distribution and networking

- Main role at the Klein Karoo National Arts Festival, South Africa: Festival promotion, Product promotion and Income generation.

- Money matters, which include aspects such as 'to make lots of money' and 'to permit me to become financially independent.'
Jackson (2005:359)

Jonker et al. (2009:388)

Getz and Peterson (2005:232)

${ }^{1}$ To date, the perceived role of entrepreneurs from different cultures has not been examined. 


\begin{tabular}{l|l}
$\begin{array}{l}\text { L. Engelbrecht } \\
\text { M. Kruger } \\
\text { M. Saayman }\end{array}$ & THE ROLE OF CULTURE WITH FESTIVAL ENTREPRENEURS \\
\hline
\end{tabular}

The characteristics of entrepreneurs (Table 2) determine the individuals' attitude towards pursuing an entrepreneurial venture or not (Figure 1). Culture, in various forms, can therefore be depicted as a moderator of the relationship between contextual factors and entrepreneurial outcomes and highlights that national culture acts as a catalyst rather than a causal agent of entrepreneurship (Hayton et al., 2002:45). According to Hayton et al. (2002:44), for this reason it is important to conduct research on entrepreneurship across cultures.

Based on this, knowledge of the influence of cultural differences on entrepreneurship at the GNAF can provide valuable insights into the entrepreneurial attributes, motivations and personal characteristics that distinguish the entrepreneurs at the festival. Determining the influence of culture on these aspects can furthermore assist festival managers to provide the relevant support to festival entrepreneurs while, at the same time, creating a more favourable entrepreneurial culture for entrepreneurs from all cultural backgrounds. This is crucial to encourage, increase and sustain entrepreneurial opportunities and thus entrepreneurship at national arts festivals in South Africa.

\section{METHOD OF RESEARCH}

Data used in the analysis were gathered during the GNAF, held from 26 June until 5 July 2008. The method of research used will subsequently be discussed under the following headings: (i) the questionnaire, (ii) the sample and (iii) statistical analysis.

\section{The Questionnaire}

The questionnaire used to survey entrepreneurs at the festival in 2008 determined the profile of the entrepreneurs, the types of businesses, the attributes of the entrepreneurs and their role at the festival as well as their main motivation to do business at the festival. The content of the questionnaire was based on the work of Barnard (1988:169), Mitton (1998:113), Olivier (2002:151) and Van der Merwe (1994:352) However, the questionnaire was adapted and slightly altered from the entrepreneurship questionnaires that were used by Saayman et al. (2008) at the Aardklop National Arts festival and Jonker et al. (2009) at the Klein Karoo National Arts Festival. The sections on entrepreneurial attributes, motivations to visit the festival, as well as entrepreneurs' perceived role at the festival were measured on a 5-point Likert scale and respondents were asked to indicate how important they considered each item ( $1=$ not at all important; 2 = less important; $3=$ important; 4 = very important and 5 = extremely important).

\section{The Sample}

Respondents included stall owners at both the main festival grounds and the Village green market at the festival. The Village Green Market consists of 231 craft stalls (situated inside the marquees), 12 outdoor stalls and 24 food stalls. While the survey was done through self-administered questionnaires, due to potential difficulties with the English language, and reading and writing deficiencies of some of the respondents, personal interviews were also held with the respondents who could not fill in the questionnaire themselves. The field workers were trained to ensure that they understood the aim of the study as well as the questionnaire so that they could distribute the questionnaires and conduct the interviews. Respondents were further briefed beforehand about the purpose of the research to ensure that they participated willingly and responded openly and honestly. Approximately three hundred (300) questionnaires were distributed during the festival, of which two hundred and fifty $(250)$ questionnaires could be statistically analysed for research purposes. Microsoft ${ }^{\odot}$ Excel $^{\odot}$ was used for data capturing and basic data analysis.

\section{Attributes of entrepreneurs at the GNAF}

As revealed by Engelbrecht, Kruger and Saayman (2010) seven entrepreneurial attributes at the GNAF (which explained $59.3 \%$ of total variance) were identified by the pattern matrix of the principal component factor analysis using Oblimin rotation with the Kaiser Normalisation. A reliability coefficient (Cronbach's alpha) was computed for each factor to estimate the internal consistency of each factor and all factors with a reliability coefficient above of 0.6 were considered as acceptable. The average inter-item correlations were also computed as another measure of reliability and all items loaded on a factor with loading greater than 0.3 . The Kaiser-Meyer-Olkin measure of sampling adequacy of 0.87 also indicated that patterns of correlation were 
relatively compact and yielded distinct and reliable factors (Field, 2005:640). All factors furthermore had relatively high reliability coefficients ranging from 0.60 (the lowest) to 0.83 (the highest). The average inter-item correlation coefficients with values between 0.36 and 0.44 also implied internal consistency for all factors. Table 3 below shows that entrepreneurs regarded Initiative (4.50), Management skills (4.41), Self-efficacy (4.23) and Resourcefulness (4.17) as the most important attributes for success as an entrepreneur. Acquired skills (3.97), Motivation for achievement (3.80) and Explorative (3.38) were seen as less important attributes. Similar to results revealed by Saayman et al. (2008) and Jonker et al. (2009), entrepreneurs at the Grahamstown National Arts Festival considered personal attributes as more important than acquired skills. However, Management skills is an attribute that can be taught or improved by means of training programmes.

Table 3: Factor analysis results of entrepreneurial attributes at the GNAF

\begin{tabular}{|c|c|c|c|}
\hline Factor 1:Self-efficacy & $\begin{array}{l}\text { Factor 2: } \\
\text { Resourcefulness }\end{array}$ & $\begin{array}{l}\text { Factor 3: Motivation } \\
\text { for achievement }\end{array}$ & "Factor 4: Acquired skills \\
\hline $\begin{array}{l}\text { Confidence } \\
\text { Independence } \\
\text { Hard work (long hours) } \\
\text { To make use of } \\
\text { opportunities } \\
\text { To always give your } \\
\text { best } \\
\text { Leadership } \\
\text { Communication }\end{array}$ & $\begin{array}{l}\text { Vision } \\
\text { Ambition } \\
\text { Creativity } \\
\text { Dedication } \\
\text { Innovation } \\
\text { Optimism } \\
\text { Calculated risks }\end{array}$ & $\begin{array}{l}\text { To always win } \\
\text { To always be successful } \\
\text { Profit driven } \\
\text { Time management }\end{array}$ & $\begin{array}{l}\text { Knowledge } \\
\text { Human relations } \\
\text { Education } \\
\text { Teamwork } \\
\text { Tolerance } \\
\text { Well thought through plans }\end{array}$ \\
\hline Factor 5: Initiative & Factor 6: Explorative & $\begin{array}{l}\text { Factor 7: Management } \\
\text { skills }\end{array}$ & Total variance explained \\
\hline Initiative & $\begin{array}{l}\text { Adventurous } \\
\text { Privacy }\end{array}$ & Management skills & $59.3 \%$ \\
\hline
\end{tabular}

\section{Statistical analysis}

SPSS (SPSS Inc, 2007) was used for the analysis of data and, in this study, it comprised two stages. Firstly, a general profile of entrepreneurs at the GNAF was compiled. Secondly, Chi-square tests as well as ANOVAs with Tukey's multiple comparisons were employed to investigate which cultural traits influenced the four cultural groups' (White, Black, Coloured and Indian) entrepreneurial behaviour. The following factors, as outlined in Figure 1, were included in the analysis: socio-demographic characteristics (age, age when business was started, gender, marital status, level of education, family business, number of years established, number of employees, percentage of shares in business, number of festivals attended and other festivals attended), entrepreneurial attributes as determined by the factor analysis outlined in Table 3 (Self-efficacy, Resourcefulness, Motivation for achievement, Acquired skills, Initiative, Explorative, and Management skills), motivation to attend the festival as well as perceived role at the festival (Evidenced) to examine whether statistically significant differences existed among different the cultural groups.

\section{RESULTS OF THE RESEARCH}

The results of the research will be discussed in two sections. Firstly, an overview of the profile of entrepreneurs attending the GNAF will be presented and, secondly, the result of the ANOVA with Tukey's multiple comparison as well as the results of the two-way frequency tables and Chi-square tests.

\section{Profile of entrepreneurs attending the GNAF}

Table 4 shows that more of the entrepreneurs at the festival are female (54\%) and English-speaking (44\%) with an average age of 40 years. Entrepreneurs started their business at the average age of 31 years indicating that they have started their business in the past ten years $(56 \%)$. Half $(50 \%)$ of the entrepreneurs are married and 

L. Engelbrecht
M. Kruger
M. Saayman

THE ROLE OF CULTURE WITH FESTIVAL ENTREPRENEURS

$46 \%$ stated that their highest level of education was matric. Although different racial groups are represented at the festival, $51 \%$ of the entrepreneurs were White followed by $35 \%$ who were Black. The business profile of the entrepreneurs at the GNAF show that $41 \%$ sell Arts and Crafts, $57 \%$ of entrepreneurs own $100 \%$ of the business shares and $89 \%$ started the business on their own. Most (46\%) businesses are operated from home in the Western Cape (38\%). Entrepreneurs attend this festival to market and expand their business and also to introduce new products. Their role at the festival is mainly to deliver a unique and quality product or service and to make a profit.

Table 4: Profile of entrepreneurs at the GNAF

\begin{tabular}{|c|c|}
\hline Category & Profile of entrepreneurs at the GNAF \\
\hline Gender & $54 \%$ female, $46 \%$ male \\
\hline Language & 44\% English \\
\hline Age & $\begin{array}{l}36 \% \text { between } 35 \text { and } 49 \text { years followed by } 27 \% \text { between } 25 \text { and } 34 \text { years and } \\
22 \% \text { between } 50 \text { and } 64 \text { years. Average age } 40.3 \text { years. }\end{array}$ \\
\hline $\begin{array}{l}\text { Age when business was } \\
\text { started }\end{array}$ & $\begin{array}{l}\text { Between } 26-30 \text { years (25\%) followed by } 20-25 \text { years }(23 \%) ; 56 \% \text { of } \\
\text { entrepreneurs at the festival started their business in the last } 10 \text { years } \\
\text { (between } 2000 \text { and 2008). Average age of } 31 \text { years when business was } \\
\text { stared. }\end{array}$ \\
\hline Marital status & $50 \%$ married, $41 \%$ single \\
\hline Level of education & $46 \%$ matric followed by $22 \%$ having a diploma. \\
\hline Race & 51\% White, 35\% Black, 10\% Coloured and 4\% Indian \\
\hline Type of business & $\begin{array}{l}\text { White: Variety ranging from Services, Manufacturing (goods), Arts \& crafts, } \\
\text { Food \& beverages and Financial services } \\
\text { Black: Manufacturing, Arts and crafts } \\
\text { Coloured: Variety ranging from Services, Manufacturing, Arts \& crafts, Food \& } \\
\text { beverages and Financial services } \\
\text { Indian: Manufacturing (goods) and Financial Services }\end{array}$ \\
\hline Shares in business & $\begin{array}{l}57 \% \text { own } 100 \% \text { shares } \\
24 \% \text { own } 50 \% \text { shares }\end{array}$ \\
\hline How business started & $89 \%$ started the business on their own. \\
\hline Operate business from & $46 \%$ operate the business from home. \\
\hline $\begin{array}{l}\text { Province from where } \\
\text { business is operated }\end{array}$ & $\begin{array}{l}38 \% \text { Western Cape } \\
30 \% \text { Eastern Cape } \\
14 \% \text { Gauteng }\end{array}$ \\
\hline $\begin{array}{l}\text { Reasons for attending } \\
\text { festival }\end{array}$ & $\begin{array}{l}\text { 1. Marketing their business } \\
\text { 2. To expand their business } \\
\text { 3. To introduce new products }\end{array}$ \\
\hline Role at festival & $\begin{array}{l}\text { 1. To deliver unique and quality products and services } \\
\text { 2. To make a profit }\end{array}$ \\
\hline
\end{tabular}

\section{Results of ANOVA and Tukey's multiple comparisons}

Race was used to distinguish between the different cultures at the festival - White, Black, Coloured and Indian. ANOVAs were employed to determine the differences between the four cultural groups at the GNAF based on certain socio-demographic characteristics, entrepreneurial attributes, and motivation to attend the festival as well as their perceived role at the festival. As shown in Table 5 , significantly more White entrepreneurs $(N=126)$ attend the GNAF followed by Black entrepreneurs $(N=88)$, while Coloured and Indian entrepreneurs are not well represented at the festival ( $N=24$ and $N=11$ respectively). This should be taken into consideration when interpreting the results of this study as discussed in the next section.

\section{Socio-demographic characteristics}

Table 5 shows that statistically significant differences exist between White, Black, Coloured and Indian entrepreneurs at the GNAF based on age $(p<0.005)$, age when business was started $(p<0.032)$, percentage 


\section{Engelbrecht \\ M. Kruger \\ M. Saayman \\ THE ROLE OF CULTURE WITH FESTIVAL ENTREPRENEURS}

of shares in business $(p<0.001)$ and the number of festivals attended $(p<0.000)$. When comparing the age among cultures, White entrepreneurs are older with an average age of 43 years while all the other cultures are in their late thirties. White and Black entrepreneurs started their entrepreneurial ventures in their thirties (33 years and 30 years respectively) while Coloured and Indian entrepreneurs started their businesses in their mid twenties (26 years and 27 years respectively). White and Black entrepreneurs have a higher percentage of shares in their businesses (83\% and $72 \%$ respectively) when compared to Coloured and Indian entrepreneurs (63\% and 64\% respectively). White entrepreneurs have attended the GNAF more often (average of 7 times), while both Coloured and Indian entrepreneurs have attended the festival an average of 6 times. Black entrepreneurs have attended the festival an average of only 4 times, which shows a growing interest in this area. This result is interesting, especially when taking into consideration that the GNAF turned 35 years old in 2008. It therefore seems that either the current entrepreneurs (irrespective of their culture) at the festival only realised the potential of the festival for their businesses in the last few years or the GNAF only marketed the festival as an attractive entrepreneurial platform over the last decade.

Even though no statistically significant differences exist between the different cultures based on age of business $(p<0.787)$ and number of employees $(p<0.848)$, the average age of Indian owned businesses is 11 years followed by White and Coloured owned businesses which are an average of 10 years old. Black entrepreneurs have only been owning their businesses for an average of 9 years. This indicates that Indian, White and Coloured entrepreneurs at the festival have more established businesses compared to the Black entrepreneurs. It seems that all four cultures employ roughly the same number of employees. Both White and Coloured entrepreneurs employ an average of 6 employees while Black and Indian entrepreneurs employ an average of 5 and 4 employees respectively.

\section{Entrepreneurial attributes}

Statistically meaningful differences exist between the different cultures at the GNAF based on the following entrepreneurial attributes: Resourcefulness, Motivation for achievement and Acquired skills. The attribute with the most significance $(p<0.000)$ is Motivation for achievement. Coloured entrepreneurs consider this attribute as the most important (4.35), compared to the White (3.55) and Indian (3.74) entrepreneurs who consider the attribute as less important. Resourcefulness $(p<0.004)$ is equally important for White (4.28) and Coloured (4.27) entrepreneurs, while Indian entrepreneurs (3.74) regard this attribute as less important. Significant differences exist between White entrepreneurs and Coloured entrepreneurs regarding Acquired skills $(p<$ 0.006). Coloured entrepreneurs regard this attribute as extremely important (4.40), while White entrepreneurs consider it less important (3.86). There are no significant differences between the different cultures based on Self-efficacy $(p<0.351)$, Initiative $(p<0.352)$, Explorative $(p<0.067)$ and Management skills $(p<0.692)$. However, it appears that Self-efficacy and Management skills are important entrepreneurial attributes to all cultures while Explorative is regarded as a less important attribute. White, Black and Coloured entrepreneurs consider Initiative as an attribute that contributes to the success of their business $(4.87,4.20$ and 4.04 respectively) while Indian entrepreneurs attach less meaning to this attribute (3.73).

\section{Motivations/reasons to attend the festival}

Concerning the motives or reasons for attending the GNAF, statistically significant differences occurred in terms of Contribution to the local community $(p<0.001)$, To contribute to the arts $(p<0.048)$ and Personal satisfaction $(p<0.029)$. Coloured entrepreneurs differ significantly from White and Indian entrepreneurs based on To contribute to the local community. Coloured entrepreneurs consider this as one of their main motivations to attend the festival (4.13) while White and Indian entrepreneurs consider it a less important reason (3.29 and 3.00 respectively). White entrepreneurs considered Personal satisfaction as a more important reason to attend the festival (4.08) than the other cultures. When looking at the other motivations/reasons, all cultures consider To make a profit, To market the business, To introduce new products and To expand existing business as extremely important reasons for attending the GNAF. On the other hand, To contribute to the growth of the festival and especially To entertain are the least important reasons for all four cultures.

\section{Perceived role at festival}

Both White (4.54) and Coloured (4.30) entrepreneurs differ significantly $(p<0.022)$ from Indian entrepreneurs based on To provide quality products/services. White (4.54) and Coloured (4.30) entrepreneurs consider that 


\section{Engelbrecht \\ M. Kruger \\ M. Saayman}

they play an extremely important role at the GNAF while Indian entrepreneurs (3.91) see this role as less important. Coloured entrepreneurs also statistically differ from Indian entrepreneurs in terms of Profit and sales $(p<0.033)$. Indian entrepreneurs (3.64) consider it a less important role while Coloured entrepreneurs (4.46) regard making money as an extremely important role for them at the festival. Other perceived roles were not significantly different between the different cultures and all four cultures perceive To provide a new and unique product/service as an important role. To support the GNAF is seen as an important role for Black, Coloured and Indian entrepreneurs $(4.00,4.13$ and 4.00 respectively), while White entrepreneurs ranked this perceived role lower (3.76). With the exception of the Coloured entrepreneurs who rate it as important (4.00), To contribute to the local community was not an important role for the White, Black and Indian entrepreneurs (3.52, 3.77 and 3.55 respectively). As stated before, this can be because the Coloured entrepreneurs are locals that share the same cultural background and therefore feel more strongly about supporting the festival since it contributes to their community. Indian entrepreneurs consider To market the business as a less important role (3.91) while the other cultures felt the opposite (respectively 4.27, 4.40 and 4.45). Social interaction is the least important role for entrepreneurs at the GNAF (between 3.55 and 3.92).

Table 5: Results of ANOVA and Tukey's post hoc multiple comparisons for visitor characteristics between different cultures

\begin{tabular}{|c|c|c|c|c|c|c|}
\hline \multirow[b]{2}{*}{ Characteristics } & \multicolumn{4}{|c|}{ Culture indicated by race } & \multirow[b]{2}{*}{ F-ratio } & \multirow[b]{2}{*}{ Sig. level } \\
\hline & $\begin{array}{l}\text { White } \\
(\mathrm{N}=126)\end{array}$ & $\begin{array}{l}\text { Black } \\
(\mathrm{N}=88)\end{array}$ & $\begin{array}{l}\text { Coloured } \\
(\mathrm{N}=24)\end{array}$ & $\begin{array}{l}\text { Indian } \\
(\mathrm{N}=11)\end{array}$ & & \\
\hline Age & 43 & 38 & 37 & 37 & 4.362 & $0.005^{*}$ \\
\hline Age when business was started & 33 & 30 & 26 & 27 & 2.979 & $0.032^{*}$ \\
\hline $\begin{array}{l}\text { Number of years established (age of } \\
\text { business) }\end{array}$ & 10 & 9 & 10 & 11 & 0.353 & 0.787 \\
\hline Number of employees & 6 & 5 & 6 & 4 & 0.268 & 0.848 \\
\hline Percentage of shares in business & 83 & 72 & 63 & 64 & 5.314 & $0.001^{*}$ \\
\hline Number of festivals attended & 7 & 4 & 6 & 6 & 8.012 & $0.000^{*}$ \\
\hline $\begin{array}{l}\text { Entrepreneurial attributes } \\
\text { Self-efficacy } \\
\text { Resourcefulness } \\
\text { Motivation for achievement } \\
\text { Acquired skills } \\
\text { Initiative } \\
\text { Explorative } \\
\text { Management skills }\end{array}$ & $\begin{array}{l}4.24 \\
4.28^{\mathrm{a}} \\
3.55^{\mathrm{a}} \\
3.86^{\mathrm{a}} \\
4.87 \\
3.33 \\
4.21\end{array}$ & $\begin{array}{l}4.16 \\
4.04 \\
4.01 \\
4.00 \\
4.20 \\
3.29 \\
4.74\end{array}$ & $\begin{array}{l}4.44 \\
4.27^{\mathrm{a}} \\
4.35^{\mathrm{b}} \\
4.40^{\mathrm{b}} \\
4.04 \\
3.94 \\
4.46\end{array}$ & $\begin{array}{l}4.25 \\
3.74^{\mathrm{b}} \\
3.73^{\mathrm{a}} \\
4.09 \\
3.73 \\
3.55 \\
4.09\end{array}$ & $\begin{array}{l}1.097 \\
4.605 \\
10.274 \\
4.254 \\
1.094 \\
2.417 \\
0.486\end{array}$ & $\begin{array}{l}0.351 \\
0.004^{*} \\
0.000^{*} \\
0.006^{*} \\
0.352 \\
0.067 \\
0.692\end{array}$ \\
\hline $\begin{array}{l}\text { Motivations/Reasons } \\
\text { To make a profit } \\
\text { To contribute to the local community } \\
\text { To contribute to the arts } \\
\text { To entertain } \\
\text { To contribute to the growth of the } \\
\text { festival } \\
\text { Personal satisfaction } \\
\text { To market the business } \\
\text { To introduce new products } \\
\text { To expand existing business }\end{array}$ & $\begin{array}{l}4.11 \\
3.29^{\mathrm{a}} \\
3.25 \\
2.55 \\
3.56 \\
4.08 \\
4.34 \\
4.03 \\
4.15\end{array}$ & $\begin{array}{l}4.07 \\
3.77 \\
3.66 \\
2.75 \\
3.78 \\
3.65 \\
4.33 \\
4.15 \\
4.43\end{array}$ & $\begin{array}{l}4.33 \\
4.13^{b} \\
3.75 \\
3.13 \\
3.96 \\
3.70 \\
4.46 \\
4.33 \\
4.71\end{array}$ & $\begin{array}{l}4.18 \\
3.00^{\mathrm{a}} \\
3.00 \\
2.45 \\
3.36 \\
3.91 \\
4.36 \\
4.27 \\
4.25\end{array}$ & $\begin{array}{l}0.421 \\
5.387 \\
2.678 \\
1.414 \\
1.318 \\
3.048 \\
0.118 \\
0.632 \\
2.625\end{array}$ & $\begin{array}{l}0.738 \\
0.001^{*} \\
0.048^{*} \\
0.239 \\
0.269 \\
0.029^{*} \\
0.950 \\
0.595 \\
0.051\end{array}$ \\
\hline $\begin{array}{l}\text { Perceived role } \\
\text { To provide a new and unique } \\
\text { product/service } \\
\text { To provide quality products/services } \\
\text { Profit and sales } \\
\text { To support the Grahamstown Arts }\end{array}$ & $\begin{array}{l}4.23 \\
4.54^{\mathrm{a}} \\
4.17 \\
3.76 \\
3.52\end{array}$ & $\begin{array}{l}4.21 \\
4.31 \\
4.18 \\
4.00 \\
3.77\end{array}$ & $\begin{array}{l}4.30 \\
4.55^{\mathrm{a}} \\
4.25^{\mathrm{a}} \\
4.13 \\
4.00\end{array}$ & $\begin{array}{l}4.00 \\
3.91^{b} \\
3.64^{b} \\
4.00 \\
3.55\end{array}$ & $\begin{array}{l}0.263 \\
3.265 \\
2.951 \\
1.508 \\
1.573\end{array}$ & $\begin{array}{l}0.852 \\
0.022^{*} \\
0.033^{*} \\
0.213 \\
0.197\end{array}$ \\
\hline
\end{tabular}




\section{\begin{tabular}{l|l} 
L. Engelbrecht & THE ROLE OF CULTURE WITH FESTIVAL ENTREPRENEURS
\end{tabular} \\ M. Kruger \\ M. Saayman}

\begin{tabular}{|l|l|l|l|l|l|l|}
\hline $\begin{array}{l}\text { Festival } \\
\text { To contribute to the local community } \\
\begin{array}{l}\text { To market the business } \\
\text { Social interaction }\end{array}\end{array}$ & 4.27 & 4.40 & $4.45^{\mathrm{a}}$ & $3.91^{\mathrm{b}}$ & 1.750 & 0.157 \\
\hline
\end{tabular}

${ }^{*}$ Statistically significant difference: $p \leq 0.05$

${ }^{a}$ Group differs significantly from type (in row) where ${ }^{\mathrm{b}}$ is indicated

\section{Chi-square test results}

Chi-square statistical tests were used to determine whether any additional significant socio-demographic and behavioural differences existed between the four cultural groups. Statistically significant differences are evident based on gender $(p<0.013)$, marital status $(p<0,014)$, level of education $(p<0,001)$, family business $(p<$ 0.000 ) and other festivals attended (Aardklop, $p<0,019$ and Klein Karoo National Arts Festival, $p<0.000$ ). As shown in Table 6, White entrepreneurs are predominantly male (64\%), whereas the entrepreneurs representing the other cultures at the GNAF are mainly female (Black 52\%, Coloured $62 \%$ and Indian 64\%). A higher percentage of White and Indian entrepreneurs are married (58\% and $55 \%$ respectively), while Black and Coloured entrepreneurs are mostly single (51\% and $54 \%$ respectively). Entrepreneurs from all cultures at the festival only have matric. However, it seems that White entrepreneurs are likely to have a higher level of education (diploma or degree). More Coloured $(62 \%)$ and White $(59 \%)$ entrepreneurs indicated that their entrepreneurial venture at the festival is a family business while Indian (46\%) and especially Black entrepreneurs (30\%) started their businesses on their own. Although the percentages are not high, White (17\%) and Black $(8 \%)$ entrepreneurs also attend the Aardklop National Arts Festival while Coloured and Indian entrepreneurs do not feel the need to attend this festival. A significant percentage of White entrepreneurs (44\%) attend the Klein Karoo National Arts Festival and Coloured entrepreneurs (29\%) also see this festival as a place to expand their business. All cultures see themselves as entrepreneurs and therefore no statistically significant differences exist between the groups. 
M. Saayman

Table 6: Chi-square test results of visitor characteristics between different cultures

\begin{tabular}{|c|c|c|c|c|c|c|c|c|}
\hline Characteristics & \multicolumn{4}{|c|}{ Culture indicated by race } & $\begin{array}{l}\text { Chi } \\
\text { square } \\
\text { value }\end{array}$ & df & $\begin{array}{l}\text { Sig. } \\
\text { level }\end{array}$ & $\begin{array}{l}\text { Phi- } \\
\text { value }\end{array}$ \\
\hline $\begin{array}{l}\text { Gender } \\
\text { Male } \\
\text { Female }\end{array}$ & $\begin{array}{l}64 \% \\
36 \%\end{array}$ & $\begin{array}{l}48 \% \\
52 \%\end{array}$ & $\begin{array}{l}38 \% \\
62 \%\end{array}$ & $\begin{array}{l}36 \% \\
64 \%\end{array}$ & 10.753 & 3 & $0.013^{*}$ & 0.208 \\
\hline $\begin{array}{l}\text { Marital status } \\
\text { Single } \\
\text { Married } \\
\text { Divorced } \\
\text { Widow/er }\end{array}$ & $\begin{array}{l}32 \% \\
58 \% \\
8 \% \\
2 \%\end{array}$ & $\begin{array}{l}51 \% \\
43 \% \\
1 \% \\
5 \%\end{array}$ & $\begin{array}{l}54 \% \\
33 \% \\
13 \% \\
0 \%\end{array}$ & $\begin{array}{l}27 \% \\
55 \% \\
18 \% \\
0 \%\end{array}$ & 20.658 & 9 & $0.014^{*}$ & 0.289 \\
\hline $\begin{array}{l}\text { Level of } \\
\text { education } \\
\text { No school } \\
\text { Matric } \\
\text { Diploma } \\
\text { Degree } \\
\text { Post graduate } \\
\text { Other }\end{array}$ & $\begin{array}{l}3 \% \\
39 \% \\
27 \% \\
20 \% \\
10 \% \\
1 \%\end{array}$ & $\begin{array}{l}7 \% \\
56 \% \\
15 \% \\
9 \% \\
1 \% \\
12 \%\end{array}$ & $\begin{array}{l}4 \% \\
54 \% \\
17 \% \\
4 \% \\
4 \% \\
17 \%\end{array}$ & $\begin{array}{l}0 \% \\
55 \% \\
18 \% \\
9 \% \\
0 \% \\
18 \%\end{array}$ & 37.742 & 15 & $0.001^{*}$ & 0.392 \\
\hline $\begin{array}{l}\text { Family } \\
\text { business? }\end{array}$ & $59 \%$ & $30 \%$ & $62 \%$ & $46 \%$ & 20.380 & 3 & $0.000^{*}$ & 0.288 \\
\hline
\end{tabular}


L. Engelbrecht

M. Kruger

THE ROLE OF CULTURE WITH FESTIVAL ENTREPRENEURS

M. Saayman

\begin{tabular}{|c|c|c|c|c|c|c|c|c|}
\hline $\begin{array}{l}\text { Yes } \\
\text { No }\end{array}$ & $41 \%$ & $70 \%$ & $38 \%$ & $54 \%$ & & & & \\
\hline $\begin{array}{lr}\text { Other festivals } \\
\text { attended } \\
\text { Aardklop } \\
\text { Innibos } \\
\text { Volksblad } \\
\text { Klein } \\
\text { National } \\
\text { Festival } & \text { Arts } \\
& \end{array}$ & $\begin{array}{l}\text { Yes }=17 \% ; \mathrm{No}=83 \% \\
\text { Yes=3\%;No=97\% } \\
\text { Yes=6\%;No=94\% } \\
\text { Yes }=44 \% ; \mathrm{No}=56 \%\end{array}$ & $\begin{array}{l}\text { Yes=8\%;No=92\% } \\
\text { Yes=2\%;No=98\% } \\
\text { Yes=9\%;No=91\% } \\
\text { Yes }=10 \% ; \mathrm{No}=90 \%\end{array}$ & $\begin{array}{l}\text { Yes }=0 \% ; \mathrm{No}=100 \% \\
\text { Yes=0\%;No=100\% } \\
\text { Yes=8\%;No=92\% } \\
\text { Yes=29\%;No=71\% }\end{array}$ & $\begin{array}{l}\text { Yes }=0 \% ; \mathrm{No}=100 \% \\
\text { Yes }=0 \% ; \mathrm{No}=100 \% \\
\text { Yes }=18 \% ; \mathrm{No}=82 \% \\
\text { Yes }=18 \% ; \mathrm{No}=82 \%\end{array}$ & $\begin{array}{l}9.918 \\
1.185 \\
2.790 \\
29.792\end{array}$ & $\begin{array}{l}3 \\
3 \\
3 \\
3\end{array}$ & $\begin{array}{l}0.019^{\star} \\
0.757 \\
0.425 \\
0.000^{\star}\end{array}$ & $\begin{array}{l}0.200 \\
0.069 \\
0.106 \\
0.346\end{array}$ \\
\hline
\end{tabular}

* Statistically significant difference: $p \leq 0.05$ 


\section{FINDINGS}

The aim of this research was to determine the influence of cultural differences on entrepreneurship at the GNAF. In answering the question as to whether culture plays a role with festival entrepreneurs, results of this research show that there are significant cultural differences based on their socio-demographic characteristics, entrepreneurial attributes, motivation to attend as well as their perceived role at the festival. These differences both support and contradict previous research as discussed in the literature review. Based on the results, the following information was revealed:

- Festival entrepreneurs are between 37 and 43 years old, which corresponds with Nair and Panday (2006), Jonker et al. (2009) and Reynolds et al. (2002) who found that individuals between the age of 25 and 44 are most likely to be involved in entrepreneurial activity.

- With regard to entrepreneurial attributes, White and Coloured entrepreneurs regard Resourcefulness as a more important attribute than Indian entrepreneurs. Coloured entrepreneurs consider Motivation for achievement as an important attribute, while White and Indian entrepreneurs regard it as less important. White entrepreneurs also differ from Coloured entrepreneurs based on Acquired skills. Coloured entrepreneurs feel that this attribute is extremely important, whereas White entrepreneurs feel it is less important.

- Festival entrepreneurs also differ based on their motivation or reason to attend. To contribute to the local community is a very important motive for Coloured entrepreneurs as opposed to White and Indian entrepreneurs who consider it less important. This result corresponds with the findings by Mitchell (2004) and Basu and Altinay (2000).

- Corresponding with Jackson (2005), Jonker et al. (2009) and Getz and Peterson (2005), White and Coloured entrepreneurs perceive their role at the GNAF as To provide quality products/services while Indian entrepreneurs do not regard this as one of their primary roles. Coloured entrepreneurs also see Profit and sales as a very important role while Indian entrepreneurs felt differently.

- White and Coloured entrepreneurs indicated that they have a family business which supports the findings by Hisrich and Peters (1995), Lordkipanidze et al. (2005) and Co (2003). However, Black and Indian entrepreneurs indicated that they did not own a family business, supporting the notion by Nair and Panday (2006) that business acumen does not necessarily run in families.

- Contradictory to the findings by Co and Mitchell (2006), Bogan and Darity Jr. (2008:2000) and Brink, Cant and Ligthelm (2003), entrepreneurs of all four different cultures at the GNAF did not have a high level of education.

- White entrepreneurs tend to be male which supports the finding by Human (1993), Brislin (2000), Safu (2003), Botha (2006) and Chitsike (2000) that entrepreneurship is largely dominated by males. However, corresponding with Brislin (2000), Black, Coloured and Indian entrepreneurs are represented by more females.

- According to the 2008 GEM report, Whites have the highest prevalence of opportunity-motivated entrepreneurial activities compared to Blacks, whereas Coloured and Indians tend to have a moderate prevalence of opportunity motivation (Herrington et al., 2008:24). Correspondingly, but also contradictory to the GEM report, White and Coloured entrepreneurs at the GNAF also attend other festivals, especially the Klein Karoo National Arts Festival, while Black and Indian entrepreneurs do not see other festivals as opportunities to expand their businesses. This might be due to ignorance of the existence of the festivals. Added to that, these entrepreneurs might not have the means to attend the festivals further away from their homes.

- The 2008 GEM report furthermore stated that Whites are more prone to start their own business at a younger age compared to Blacks (Herrington et al., 2008:23). However, White entrepreneurs at the GNAF started their business in their early thirties which is significantly older compared to Black, Coloured and Indian entrepreneurs who started their businesses in their twenties.

\section{IMPLICATIONS AND CONCLUSION}

Based on these findings, it is clear that culture plays a significant role for festival entrepreneurs at the GNAF. This supports the notion by Urban (2006) that entrepreneurs are profoundly influenced by their cultural traits 


\section{Engelbrecht \\ M. Kruger \\ M. Saayman}

as this also has a direct influence on the way these entrepreneurs make use of the opportunities created by the festival. The unique characteristics and traits possessed by the different cultural subgroups at the festival therefore need to be acknowledged and managed to ensure a thriving entrepreneurial environment for all entrepreneurs at the festival. However, with the aim of achieving this, Maré (2001) points out that determining the factors that promote cross-cultural entrepreneurship needs to be an integral facet of entrepreneur-directed education and management as this will develop a positive orientation towards entrepreneurship. The factors that lead to the success or failure of entrepreneurs can be both internal and external. Based on the significant influence of both internal and external factors on entrepreneurship as well as the diversity of entrepreneurs at the GNAF, the following managerial options are proposed:

Firstly, seeing that festival entrepreneurs do not have a high level of education, it is vital that they get the necessary training. Training should include aspects such as pricing, production of quality products and services, selling, financial management, packaging, how to conduct business and layout of stands. Government as well as the GNAF management should also create and provide a favourable environment where entrepreneurs can obtain the necessary knowledge and skills to be successful. Training should be twofold: firstly, the current festival entrepreneurs should get the training indicated above and, secondly, potential or new entrepreneurs should be recruited - preferably from local communities.

Secondly, the festival management can form partnerships with universities such as Rhodes University in Grahamstown to help in developing festival entrepreneurs. To ensure new and creative products and services, the enhancement of innovation will be critical. This is especially important seeing that universities are responsible for addressing the need for a more entrepreneurial workforce in general, and for greater competence in this area (Rasmussen \& Sørheim, 2006:185).

Lastly, the results indicated that White, Black, Coloured and Indian entrepreneurs have attended the GNAF an average of 4 to 7 times. Taking into consideration that the festival is 35 years old, the current entrepreneurs have only recently realised the potential of doing business at the festival. For the GNAF to sustain the entrepreneurial culture at the festival, management should focus on fostering long-term relationships with current and potential entrepreneurs. Therefore the festival has to promote and market entrepreneurial opportunities at the festival more intensively. Since the festival currently attracts more entrepreneurs from the Western Cape (Table 4), the GNAF should also place more emphasis on attracting local entrepreneurs from the Eastern Cape. Coloured entrepreneurs are not well represented at the festival. These entrepreneurs perceive their main role at the festival as 'to contribute to the local community' and community involvement should therefore be encouraged through culture-specific marketing. This will greatly contribute to the upliftment of the local community. The GNAF should also focus its marketing strategies and promotional messages on attracting entrepreneurs from all racial and cultural backgrounds thereby ensuring racial equity at the festival.

This research has made a valuable contribution to ways of growing entrepreneurship among different cultures at national arts festivals. It is recommended that this type of research be applied to other national arts festivals in South Africa to compare results. However, emphasis should not only be placed on national arts festivals but also smaller community-based festivals. Expanding the knowledge base regarding the role of culture in entrepreneurship can lead to a better understanding of entrepreneurs in the country as well as the best ways to provide the necessary support to ensure entrepreneurial success. 


\section{Engelbrecht \\ M. Kruger \\ M. Saayman \\ THE ROLE OF CULTURE WITH FESTIVAL ENTREPRENEURS}

\section{REFERENCES}

ANON. 2008. Standard bank festival. http://www.nafest Date of access: 18 Feb 2008.

BARNARD, A.F. 1988. Omgewingsverkenning by 'n geselekteerde groep kleinsakeondernemings in die PWV-gebied. Potchefstroom: PU for CHE. (Dissertation - MBA). 209p.

BASU, A. \& ALTINAY, E. 2000. An exploratory study of Turkish Cypriot small businesses in London. Paper presented at the Third International Congress on Cyprus Studies, Gazimagusa, November 13-17.

BOGAN, V. \& DARITY, W. 2008. Culture and Entrepreneurship? African American and Immigrant Self-Employment in the United States. Journal of Socio-economics, 37(5):1999-2019.

BOTHA, M. 2006. Measuring the effectiveness of the woman entrepreneurship programme training intervention, on potential, start up and established women entrepreneur in South Africa. Pretoria: University of Pretoria. (Thesis - PhD). http://upetd.um.co.za/thesis/available/erd-11152006-154856 Date of access: 14 Feb 2010.

BRINK, A., CANT, M. \& LIGTHELM, A. 2003. Problems experienced by small businesses in South Africa. (Paper presented at the $16^{\text {th }}$ Annual Conference of small enterprise association of Australia and New Zealand held at the University of Ballarat, Australia from 28 September to 1 October 2003. p.20.)

BRISLIN, R. 2000. Understanding culture's influence on behaviour. $2^{\text {nd }}$ ed. Forth Worth: Harcourt College Publishers. 468p.

CHITSIKE C. 2000. Culture as a barrier to rural women's entrepreneurship. (In Sweetman C, ed. Gender in the 21st Century. Simi Valley, CA: Oxfam. p.119.)

CO, M.J. 2003. A socio-cultural explanation of black entrepreneurship in South Africa. South African Journal of Business Management, 34(4):40.

CO, M.J. \& MITCHELL, B. 2006. Entrepreneurship education in South Africa: a nationwide survey. Education and Training, 48(5):348-359.

DAVIES, T.A. 2001. Entrepreneurship Development in South Africa: Redefining the Role of Tertiary Institutions in a Reconfigured Higher Education System. South African Journal of Higher Education, 15(1):32-39.

DWYER, L., FORSYTH, P. \& SPURR, R. 2005. Estimating the Impacts of Special Events on an Economy. Journal of Travel Research, 43(4):351-359.

ENGELBRECHT, L., KRUGER. M. \& SAAYMAN, M. 2008. Analysis of Entrepreneurs at the Grahamstown National Arts Festival. Institute for Tourism and Leisure Studies: Potchefstroom. 27p. (Unpublished.)

FIELD, A. 2005. Discovering statistics using SPSS. $2^{\text {nd }}$ ed. London; Thousand Oaks: SAGE Publications. $770 \mathrm{p}$.

FREDLINE, L., JAGO, L. \& DEERY, M. 2003. The development of a generic scale to measure the social impacts of events. Event Management, 8(1):23-37.

GETZ, D. \& PETERSEN, T. 2005. Growth and profit-oriented entrepreneurship among family business owners in the tourism and hospitality industry, International Journal of Hospitality Management, 24(1):219242.

GORDON, C. 1996. The Business Culture in France. Butterworth-Heinemann, Oxford. 172p. 


\section{Engelbrecht \\ M. Kruger \\ M. Saayman \\ THE ROLE OF CULTURE WITH FESTIVAL ENTREPRENEURS}

GURSOY, D., KIM, K. \& UYSAL, M. 2004. Perceived impacts of festivals and special events by organisers: an extension and validation. Tourism Management, 25(2):171-181.

HAYTON, J.C., GEORGE, G. \& ZAHRA, S.A. 2002. National culture and entrepreneurship: A review of behavioural research. Entrepreneurship Theory and Practice, 26(4):33-52.

HERRINGTON, M., KEW, J. \& KEW, P. 2008. Global entrepreneurship monitor. 58p. http://www.gemconsortium.org Date of access:10 Jan 2010.

HISRICH, R.D. \& PETERS, M.P. 1998. Entrepreneurship. Irwin McGraw-Hill, Boston, MA. 663p.

HOFSTEDE, G. 1991. Cultures and Organisations: Software of the Mind. McGraw Hill, London. http://www.cecc.com.au/programs/resource manager/accounts/seaanz papers/NewdocCant.pdf Date of access: 25 Jan 2010.

HUMAN, P. 1993. Affirmative Action and the Development of People: A Practical Guide. Kenwyn: Juta and Co. Ltd. 108p.

JACKSON, M.J. \& O'SULLIVAN, D. 2002. Festival Tourism: A contributor to sustainable local economic development? Journal of Sustainable Tourism, 10(4):325-342.

JONKER, E., SAAYMAN, S. \& DE KLERK, S. 2009. The role and attributes of entrepreneurs at South Africa's largest arts festival. Journal of Tourism and Cultural Heritage, 7(3):381-392.

KUIPER, Y. 1993. Adel in Friesland 1780-1888 [Nobility in Friesland]. Groningen: Wolters- Noordhoff/Egbert Forsten.

LEE, S.M. \& PETERSON, S.J. 2000. Culture, entrepreneurial orientation, and global competitiveness. Journal of World Business, 35(4):401-416.

LINDSAY, N.J. 2005. Toward a cultural model of indigenous entrepreneurial attitude. Academy of Marketing Science Review, 5. http://www.amsreview.org/articles/lindsay05-2005.pdf Date of access 12 Feb 2010.

LORDKIPANIDZE, M., BREZET, H. \& BACKMAN, M. 2005. The entrepreneurship factor in sustainable tourism development. Journal of Cleaner Production, 13(1):787-798.

LUIZ, J. 2002. Small business development, entrepreneurship and expanding the business sector in a developing economy: The case of South Africa. Journal of Applied Business Research, 18(2):53-69.

MAASDORP, E.F.de V. \& VAN VUUREN, J.J. 1998. Ondernemingsbestuur.2nd ed. Van Schaik. p.727-728.

MARÉ, G. 2001. From "traditional authority" to "diversity management" some recent writing on managing the workforce. Psychology in society, 27(1):109-119.

MINNITI, M \& BYGRAVE, W.D. 2003. National entrepreneurship assessment United States of America. GEM Global Entrepreneurship Monitor, Babson College.

MITCHELL, R.K. 2003. A transaction cognition theory of global entrepreneurship. (In J.A. Katz, \& D.A. Shepherd (Eds.), Advances in entrepreneurship, firm emergence and growth, Vol. 6: 181-229. Greenwich, CT:JAI Press.)

MITTON, D.M. 1998. Entrepreneurskap na tersiêre opleiding. Vanderbijlpark: PU for CHE. (Thesis: MBA). $118 p$. 


\section{Engelbrecht \\ M. Kruger \\ M. Saayman \\ THE ROLE OF CULTURE WITH FESTIVAL ENTREPRENEURS}

MORRISON, A. 2000. Entrepreneurship: what triggers it? International Journal of Entrepreneurial Behaviour and Research, 6(2):59-71.

MUELLER, S.L. \& THOMAS, A.S. 2000. Culture and entrepreneurial potential: A nine country study of locus of control and innovativeness. Journal of Business Venturing, 16(1):51-75.

NAIR, K.R.G. \& PANDAY, A. 2006. Characteristics of entrepreneurs: an empirical analysis. Journal of Entrepreneurship, 15(1):47-61.

NIEMAN, G. 2001. Training entrepreneurs and small business enterprises in South Africa: A situational analysis. Education and Training, 43(8/9):445-450.

OLIVIER, E. 2002. Opportunities for Small, Medium and Micro-Tourism Enterprises in South Africa. Potchefstroom: PU for CHE. (Thesis - M.Com). 166p.

ORFORD, J., WOOD, E., FISHER, C. HERRINGTON, M. \& SEGAL, N. 2003. Global Entrepreneurship Monitor. UCT Graduate School of Business. www.gsb.uct.ac.za/cie Date of access: 13 Mar 2010.

RASMUSSEN, E.A. \& SØRHEIM, R.S. 2006. Action-based entrepreneurship education. Technovation, 26(2):1985-194.

REYNOLDS, P.D., BYGRAVE, W.D., AUTIO, E., COX, L.W. \& HAY, M. 2002. Global entrepreneurship monitor, 2002 executive report. Babson College, London Business School and Kauffman Foundation.

RICHIE, J.R.B. 1984. Assessing the impact of hallmark events: Conceptual and research issues. Journal of Travel Research, 23(1):2-11.

SAAYMAN, M., DOUGLAS, M. \& DE KLERK, S. 2008. Attributes of entrepreneurs at an arts festival. Southern African Journal of Entrepreneurship and Small Business Management, 2(1):17-29.

SAFFU, K. 2003. The role and impact of culture on South Pacific Island entrepreneurs. International Journal of Entrepreneurial Behaviour and Research, 9(2):55-73.

SCHINDEHUTTE, M., MORRIS, M \& BRENNAN, C. 2003. Entrepreneurs and Motherhood: Impacts on their Children in South Africa and the United States. Journal of Small Business Management, 41(1):94-107.

SCHUMPETER, J. 1934. The theory of economic development: An inquiry into profits, capital, credit, interest, and the business cycle, Harvard Economic Studies 46. Harvard University Press, Cambridge, MA.

SNOWBALL, J.D. 2004. Interpreting economic impact study results: spending patterns, visitor numbers and festival aims. South African Journal of Economics, 72(5):1075-1083.

SPSS Inc. 2007. SPSS $\AA^{\circ} 16.0$ for Windows, Release 16.0.0, Copyright@ by SPSS inc., Chicago, Illinois. www.spss.com

TYSON, B., HAYLE, C., TRULY, D., JORDAN, L.A. \& THAME, M. 2005. West Indies world cup cricket: hallmark events as catalysts for community tourism development. Journal of Sports Tourism, 10(4):323-334.

URBAN, B. 2006. Entrepreneurship in the rainbow nation: effect of cultural values and ESE on intentions. Journal of Developmental Entrepreneurship, 11(3):171-186.

VAN DER MERWE, M. 1994. 'n Entrepreneurskapontwikkelingsmodel vir werskepping as sosiale investering van ondernemings. Potchefstroom: PU for CHE. (Thesis). 356p. 

L. Engelbrecht
THE ROLE OF CULTURE WITH FESTIVAL ENTREPRENEURS
M. Kruger
M. Saayman

VAN ZYL, C. \& STRYDOM, J.W. 2007. The use of game theory to determine the optimum market position of selected arts festivals in South Africa. South African Business Review, 11(3):121-143.

VIJAYA, V. \& KAMALANABHAN, T.J. 1998. A scale to access entrepreneurial motivation. Journal of Entrepreneurship, 7(2):183-198.

VISAGIE, J.C.1999. The influence of affirmative action on SMME culture in South Africa. International journal, 7(6):148-162. www.info.gov.za/aboutsa/economy.htm Date of access: 24 Feb 2010.

VISSER, D.J., DE CONING, T.J. \& SMIT, E.v.d.M. 2005. The relationship between the characteristics of the transformational leader and the entrepreneur in South African SMEs. South African Journal of Business Management. 36(3):51-63.

WEBER, M. 1958. The religion of India: The sociology of Hinduism and Buddhism. Free Press, Glencoe, IL. $392 p$. 